\title{
Growth of Young Spruce Plantations in Interior British Columbia
}

by

Alan Vyse1

\begin{abstract}
Ninety young plantations of Interior Spruce (Picea glauca (Moench) Voss or Picea engelmannii Parry or a natural hybrid of these species) in the Cariboo Forest Region, British Columbia were assessed for growth performance. Total and internode heights of 20 to 40 undamaged planted seedlings were measured in each plantation using $50 \mathrm{~m}^{2}$ plots to select sample seedlings.

There were few striking differences in performance between stock types, site treatment types, season of planting, competing vegetation classes and ecological subzones. Good performance was found in part of the Sub-Boreal Spruce subzone, and poor performance was associated with either wet sites or dry sites. The performance of individual plants was highly variable and this could reduce potential plantation yields. Almost all plantations suffered a two year period of slow growth after planting. The one year old plug stock from styroblock containers grew more rapidly in the first year than bareroot stock types thus recovering from an initial size disadvantage. However, there was a marked decline in the second year growth of plus stock before a return to normal growth in the third year. The overall performance of small one year old seedlings suggest that size is over-emphasized in discussions of stock quality. The performance of all stock types was superior to recorded growth rates for natural seedlings of Interior Spruce.

Suggestions are made for improving plantation performance and a simple growth performance guide is presented to help forest managers identify desirable, acceptable and unsatisfactory plantations of Interior Spruce.
\end{abstract}

\section{Résumé}

Quatre-vingt-dix jeunes plantations d'épinette de l'intérieur du continent: de l'épinette blanche (Picea glauca (Moench) Voss, de l'épinette d'Engelman (Picea Engelmanii (Parry) ou un hybride naturel de ces deux espèces installées dans la région forestière de Cariboo en Colombie-Britannique ont été étudiées pour leur croissance. La hauteur totale et la longueur des entrenoeuds de 20 à 40 tiges, choisies et de bonne venue ont été mesurées dans chaque plantation sur une place-échantillon de $50 \mathrm{~m}^{2}$. II y a peu de différences marquées entre les divers stocks, les traitements de sols, la période de plantations, la compétition et les sous-zones écologiques. Les meilleurs résultats sont associés en partie à la sous-zone de l'épinette subboréale et les plus faibles, au degré d'humidité du sol (sec ou mouilleux).

La variabilité individuelle est très grande et pourrait affecter le potentiel des plantations. La plupart des plantations ont montré au cours des deux premières années, une croissance relativement lente. Les plants élevés en bloc de styrofoam ont montré une croissance supérieure à celle des plants à racine nues, rattrapant le désavantage dû à leur petitesse au moment de la plantation. La seconde année, cependant, ces plants élevés en bloc ont ralenti leur développement de façon marquée pour reprendre une croissance relativement normale en troisième année. Dans l'ensemble, il apparaît que la grosseur initiale semble surestimée comme critère de qualité dans la production de plants. De plus, le rendement de tous les types de plants rencontrés est supérieur en terme de croissance à celui des sauvageons. Des recommandations sont données en vue d'améliorer le rendement des plantations et un guide est proposé au forestier pour qualifier les plantations d'épinettes de l'intérieur du continent comme désirables, satisfaisantes ou indésirables.

1Research Forester, Cariboo Region, British Columbia Ministry of Forests, Williams Lake, BC.

\section{Introduction}

White Spruce (Picea glauca (Moench) Voss) and Engelmann Spruce (Picea engelmannii Parry) are widely reported to grow slowly in the years immediately following planting (Stiell 1976; Dobbs 1972). And in British Columbia (BC) I have found that this phenomenon is so well rooted in the minds of reforestation specialists, that slow growth problems are expected and are considered normal. This could be a costly state of mind. In 1980 some 37 million Interior Spruce $^{2}$ were planted in the province and this number may well be doubled by 1990 . If early growth problems could be avoided, the cumulative benefits would be substantial. I therefore undertook a survey of successful young Interior Spruce plantations in the Cariboo region of BC to find out what normal early growth is, and in describing that state to assess future consequences for plantation management, and to uncover possible routes to improvement.

The Cariboo Region is an administrative unit of the Ministry of Forests in the south central portion of the province. All the spruce plantations surveyed had been established between the latitudes of $51-1 / 2^{\circ}$ north and $53-1 / 2^{\circ}$ north on the rolling plateau lands of the Quesnel Highlands. Annual precipitation ranges from 60 to 120 centimetres, and occasional summer droughts result in moisture deficits. Ecological classification studies have placed the plantation sites in three biogeoclimatic zones Sub-Boreal Spruce, Interior Cedar Hemlock and Engelmann Spruce Sub-Alpine Fir - and the soils are generally classed as Luvisols, Podzols, or intergrades of these orders (Annas and Coupé 1979).

\section{Methods}

One hundred plantations of Interior Spruce established between 1968 and 1977 were surveyed through the summer of 1979. They were selected to represent major stock types and site preparation methods, both planting seasons, and a range of ecological conditions and current vegetation cover. Their distribution by sampling variables is shown in Table 1.

The estimated survival rate of surveyed plantations obtained from Ministry of Forests or company records is shown in Table 2. Plantations with very low survival rates were not sampled because of practical difficulties.

Each plantation was surveyed for height growth by measuring total and internode heights from the ground of all undamaged planted seedlings within the circumference of a $50 \mathrm{~m}^{2}$ plot. Plots were located first by identifying the largest site type within the plantation boundary and then at $50 \mathrm{~m}$ intervals in a random direction from some convenient starting point within the type. Between 20 and 40 seedlings were measured in each plantation. This total was sufficient to produce an estimate of mean total height with a standard error of less than $5 \mathrm{~cm}$.

The results of the survey have been analyzed using simple descriptive statistics. No specific hypotheses were subjected to statistical tests. All values shown in Figures 1 and 2 are means of plantation means. 
Table 1. Distribution of plantations and samples by ecological zone, stock type, site preparation method, present vegetative competition class and season of planting.

\begin{tabular}{|c|c|c|c|}
\hline \multirow[t]{2}{*}{ Category } & \multicolumn{3}{|c|}{ Stock Type } \\
\hline & $1+0$ Plug & $2+0$ Bareroot & $2+1$ Bareroot \\
\hline \multicolumn{4}{|l|}{ 1. Ecological zone ${ }^{1}$} \\
\hline - SBS(c) & 11 & 13 & 17 \\
\hline - $\mathrm{ICH}(\mathrm{b})$ & 0 & 6 & 2 \\
\hline$-\mathrm{ICH}(e)$ & 4 & 6 & 14 \\
\hline - ESSF(h) & 11 & 8 & 8 \\
\hline \multicolumn{4}{|l|}{ 2. Site Preparation } \\
\hline burn or wildfire & 20 & 28 & 27 \\
\hline - Windrow & 0 & 2 & 4 \\
\hline - Planting trails & 1 & 0 & 1 \\
\hline - None & 5 & 3 & 9 \\
\hline \multicolumn{4}{|l|}{$\begin{array}{l}\text { 3. Present Vegetative } \\
\text { Competition }\end{array}$} \\
\hline - Light & 3 & 7 & 9 \\
\hline - Moderate & 17 & 18 & 22 \\
\hline - Heavy & 6 & 8 & 10 \\
\hline \multicolumn{4}{|l|}{ 4. Season of Planting } \\
\hline - Spring & 26 & 32 & 28 \\
\hline - Fall & 0 & 1 & 13 \\
\hline
\end{tabular}

1SBS - Sub-Boreal Spruce, ICH — Interior Cedar Hemlock, ESSF - Engelmann Spruce Sub-Alpine Fir; the lower case letter indicates subzone.

Table 2. First or second year survival rates by stock types and by ten percentile classes for plantations sampled in early growth study.

$$
\text { Median }
$$
Survival class - percen No.

$\begin{array}{llllllllll}\text { Stock type survival } & 30 & 40 & 50 & 60 & 70 & 80 & 90 & 100 \text { data } & \text { Total }\end{array}$ $\%$ number of plantations

$1+0$

\begin{tabular}{lllllllllllll}
$\begin{array}{l}\text { Plug } \\
+0\end{array}$ & 91 & - & - & 2 & 1 & 3 & - & 4 & 13 & 3 & 26 \\
$\begin{array}{l}\text { Bareroot } \\
\begin{array}{l}+1 \\
\text { Bareroot }\end{array}\end{array}$ & 79 & - & 1 & 2 & 1 & 5 & 6 & 5 & 7 & 6 & 33 \\
\hline
\end{tabular}

\section{Results}

The plantation data were examined for differences in growth between competing vegetation classes, site treatment types, stock types, season of planting, and ecological zone. Some comparisons were restricted because of lack of data.

a. Stock Type Differences

No striking stock type differences were revealed in either means or dispersion (see Figures 1 and 2)

b. Superior Growth Pattern

All plantations exhibiting superior growth, defined as plantations with mean 4 year height in the top $15 \%$ of the plantations surveyed, were located on relatively low elevation "good" site lands north and east of Quesnel in the Sub-Boreal Spruce (c) ecological subzone. Both bareroot and container stock types were represented.

c. Inferior Growth Pattern

Poor height growth in all stock types was associated with either wet sites (usually where the water table had risen after logging), or dry sites (associated with southern aspects or windrowing on coarse parent material). Surprisingly, heavy vegetative competition did not reduce growth, although it was observed to reduce survival. This is probably a reflection of an inadequate qualitative method of assessing competition rather than any special feature of the planting stock.

d. Variable Tree Growth

Within each plantation and within sample plots in the plantation, growth was highly variable (Table 3 ). This variation cannot be attributed to major site differences because plantations were stratified before sampling, and because much variation was found within each sample plot. Similarly, stock quality and planting quality are unlikely to be contributory courses because one would expect each to be relatively uniform within a $50 \mathrm{~m}^{2}$ plot. Thus such differences are most probably the result of an interaction between genetic and micro-site factors.

Table 3. Some examples of variation in the total height within a plantation.

\begin{tabular}{|c|c|c|c|c|c|c|c|}
\hline \multirow{2}{*}{\multicolumn{2}{|c|}{ Piantation }} & \multicolumn{6}{|c|}{ Time from planting } \\
\hline & & \multicolumn{3}{|c|}{5 years } & \multicolumn{3}{|c|}{10 years } \\
\hline No & Stock type & Mean & SD & CV & Mean & SD & CV \\
\hline & & $\mathbf{c m}$ & $\mathrm{cm}$ & $\%$ & $\mathrm{~cm}$ & $\mathrm{~cm}$ & $\%$ \\
\hline$A 6-1$ & $2+1 B R$ & 50.3 & 14.6 & 29 & 142.8 & 36.9 & 26 \\
\hline A6-1 & $2+0 \mathrm{BR}$ & 61.5 & 22.6 & 37 & 160.0 & 55.7 & 35 \\
\hline G1-59 & $1+0 P$ & 48.6 & 17.2 & 35 & & & \\
\hline G1-55 & $2+0 B R$ & 56.4 & 22.6 & 40 & & & \\
\hline H3-3 & $2+1 B R$ & 51.5 & 14.0 & 27 & & & \\
\hline B16-15 & $2+0 B R$ & 68.1 & 20.9 & 31 & & & \\
\hline B16-15 & $1+0 P$ & 72.8 & 14.4 & 20 & & & \\
\hline G8-2 & $2+0 \mathrm{BR}$ & 43.6 & 9.6 & 22 & & & \\
\hline
\end{tabular}

\section{e. Slow Early Growth}

Almost all plantations passed through two seasons of slow height growth before beginning an accelerating growth pattern. Sometimes the "check" lasted three years. In this period annual growth rarely exceeded $8 \mathrm{~cm}$. A smaller proportion (approximately $50 \%$ ) of plantations suffered a decline of growth in the second year (Figure 4). It was most marked in one year old plug stock. A very small number of plantations experienced marked growth acceleration after the first year.

f. Season of Planting

There was little difference in the growth performance of fall and spring planted transplant $(2+1)$ stock. Other stock types had been planted only in the spring.

\section{Discussion and Conclusions}

1. The "normal" growth trend of Cariboo plantations, when compared with reported results of plantations elsewhere in BC and in Ontario (Armit 1970; Burgar and Lyon 1968; Coates 1974; Van Eerden 1979) is unexceptional neither very good nor very bad (as Figure 5 shows). However, the data available on the early growth of natural seedlings for BC and Alberta (Eis 1970; Johnstone 1976; Smith and Wass 1979) suggest that if plantations are established immediately following logging they will gain a substantial early advantage over natural regeneration despite planting shock. Another encouraging sign is the distinct recovery of growth two years after planting. This contrasts strongly with the worrying performance of early plantations in the Prince George area reported by Coates (1974), and suggests that many of the early problems connected with nursery practices, stock handling, and planting have been overcome.

2. Most plantations examined passed through a stage of slow early growth or planting shock lasting two or three years. This phemomenon is common in spruce species (see for example Armit 1970; Burgar and Lyon 1968; Mullin 1964). Most authors feel it is caused by partial root 


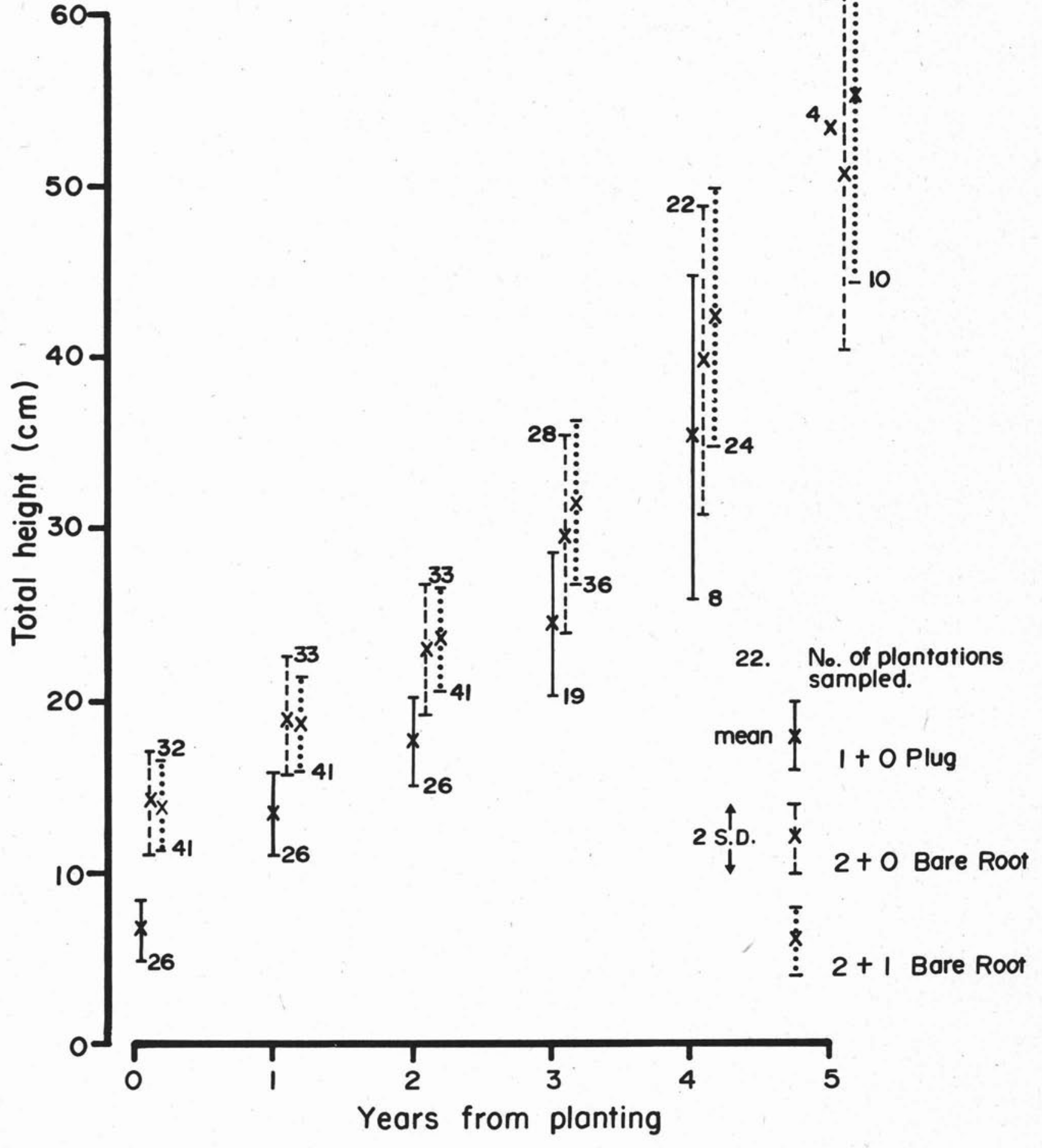

Fig. 1. Total height growth of plantations based on sample means.

system loss during planting, the slow development of a fine root system after planting, vegetative competition, and frost, in various combinations (see for example, Sutton 1972). However, these ideas do not fully explain the performance of one year old plug stock type which grew more rapidly in the first year after planting than other stock types and then slowed markedly in the second year (Figure 4). A more detailed hypothesis is needed and part of the answer is supplied by the work of Pollard and Logan (1977 and 1979). Their work on the morphogenesis of buds in White Spruce ( $P$. glauca) has shown that the annual complement of new foliage is determined in the 


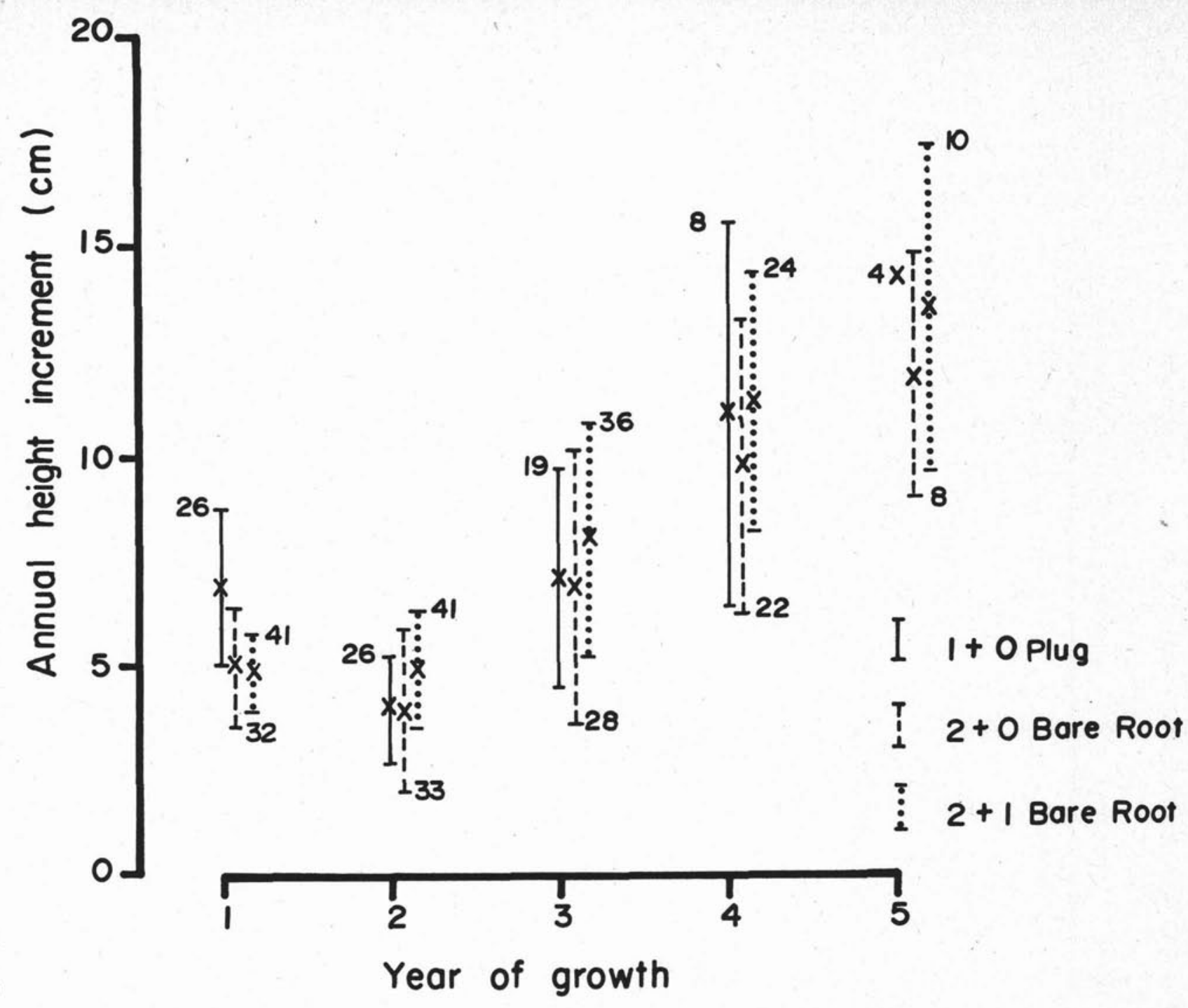

Fig. 2. Annual height increment of plantations based on sample means.

previous year and can be estimated by examining primordia in the over-wintering bud. Ambient temperature, soil moisture, light intensity and nutrient supply have all been shown to influence bud development and the number of primordia. These results, when combined with the knowledge that shoot growth is correlated with needle complement for many coniferous species (Pollard and Logan 1979), lead to the proposition that shoot growth in the first year after planting is influenced by nursery effects on bud development, as well as the ability of the seedlings to supply moisture and nutrients for bud expansion. Thus, in the case of container seedlings, one can hypothesize that rapid first years growth is a measure of the successful control of growing conditions for seedlings in the nursery, as well as the ability of the root plug to supply moisture after planting. The poorer first year performance of bareroot stock is a measure of the difficulties faced in controlling the growing conditions of individual plants in bareroot nursery beds, as well as deficient root systems at the time of planting.

Planting check in the Cariboo probably costs between one and two years of growth. This loss might be avoided by:

a) Raising the root growth capacity of seedlings at the time of planting (Brix 1979; Burdett 1979). b) Enhancing the development of over-wintering buds on planting stock by improving nursery practices (Pollard and Logan 1979).

c) Improving the planting environment by site preparation before planting or fertilization at the time of planting (e.g. McMinn 1976; Söderström et al. 1978).

d) Minimizing stock handling (Sutton 1980, quoting New Zealand experience).

3. In some plantations check was prolonged beyond the initial establishment years. This could be attributed to inadequate moisture on some sites, and better species selection will solve this problem in future years. On other sites the problem was too much moisture. Such sites are quite common at the eastern edge of the Fraser plateau where precipitation is moderately high and a fine textured basal till impedes drainage. Spruce is the best species choice, but aerated soil is required for good root growth. This can be provided by mounding, probably by use of a plough, or by instructing planters to choose well drained hummocks and to ignore normal spacing requirements. Planting check was prolonged by competition from minor vegetation in only a few cases. More examples of this problem can be expected as logging advances up mountain valleys where slopes with seepage areas support a profuse development of shrubs and 
herbs, and site preparation is difficult.

4. The widely accepted premise that "bigger is better" when planting seedlings was not supported by the results of this study. Over the wide range of the Cariboo sites, the one year plug stock with an average size of $8 \mathrm{~cm}$ performed equally well as the two and three year bareroot stock that was almost twice as big at planting $(14 \mathrm{~cm})$. While this conclusion definitely lends support to the proponents of mini-container systems, the advantages of large initial size cannot be lightly disregarded for four reasons:

i) Large plug stock from containers ranging in volume from $125 \mathrm{cc}$ to $250 \mathrm{cc}$ has been observed to outper- form small plug stock (40 cc) of the type examined in this study (Van Eerden 1979; Burdett 1981).

ii) The smaller container stock performed poorly on several brushy sites, although the other stock types also performed poorly.

iii) None of the plantations was subjected to severe drought conditions which supposedly favour larger stock types. However, it is doubtful if spruce plantation sites in the Cariboo Region ever experience severe drought.

iv) The bareroot stock, although larger, was probably of poor quality, especially the transplants, which were mostly derived from $2+0$ stock judged too small for

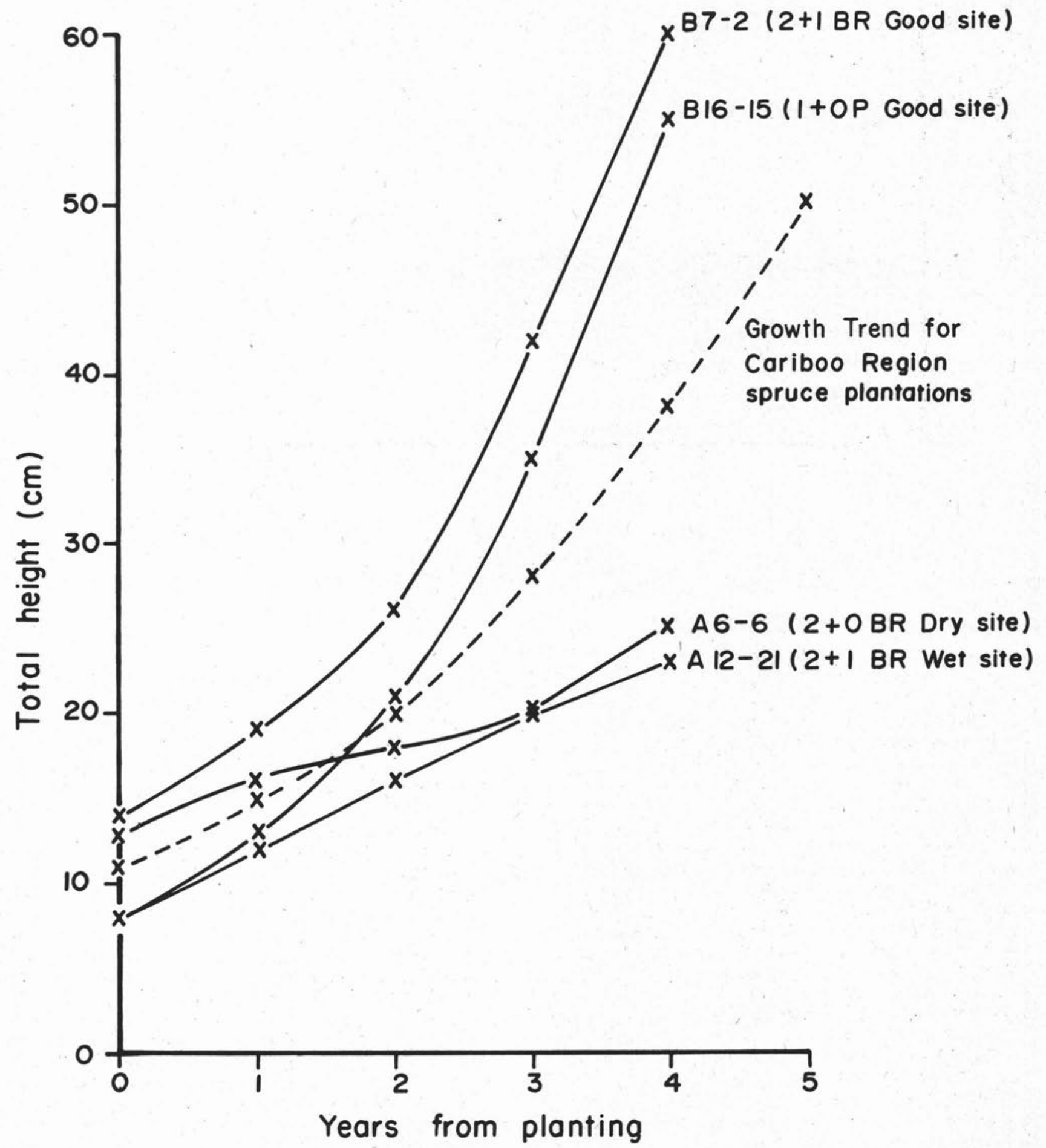

Fig. 3. Total height growth of superior and inferior plantations. 
planting. Very few plantations were planted with bareroot stock that achieved the minimum standard of $15 \mathrm{~cm}$ total height set for easy sites by Revel (1978). The same is true for the container stock, however, as none of it exceeded $60 \%$ of the target for seedling height set by Van Eerden (1975).

Despite these qualifying remarks, the results do give force to the argument that size is over-emphasized in discussions about planting stock. At least for Cariboo conditions the link between initial size and subsequent growth performance is very weak, and future investigations should concentrate on improving the ability of seedlings to grow rapidly once planted, regardless of size.

5. The highly variable performance of individual seedlings in all plantations may prove to be a serious future problem because actual yield may prove to be much less than potential yield. As an example, consider a plantation with an initial spacing of 1,250 stems/hectare and with initial mortality of $30 \%$, leaving 875 stems/hectare remaining. According to work done by Bella and DeFranceschi (1978) in Alberta, this number of stems would just suffice for crown closure and full site occupancy between 40 and 50 years. If harvesting was planned at 70 or 80 years it is unlikely that competition would remove more than a small percentage of inferior stems unless growth was very rapid. With a coefficient of variation of $25 \%$ (see Table 2 for actual values after 5 and 10 years) about $16 \%$

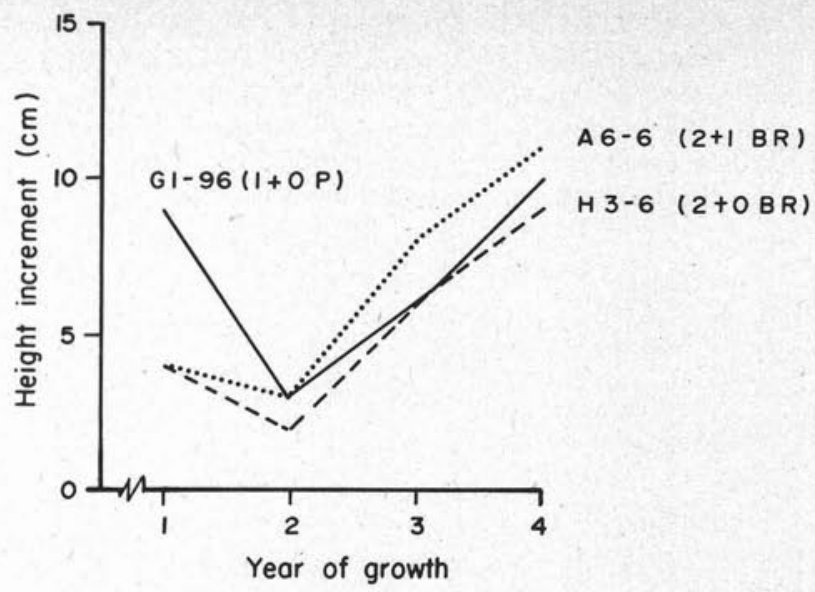

Fig. 4. Examples of reduced second year growth.

of the intended crop trees would be less than $75 \%$ of mean crop tree height. A more uniform stand of crop trees could be produced by a combination of increasing planting densities and reducing initial mortality, followed by juvenile spacing.

Mitchell (1978) using a tree and stand growth simulator has examined the effect of encouraging natural selection

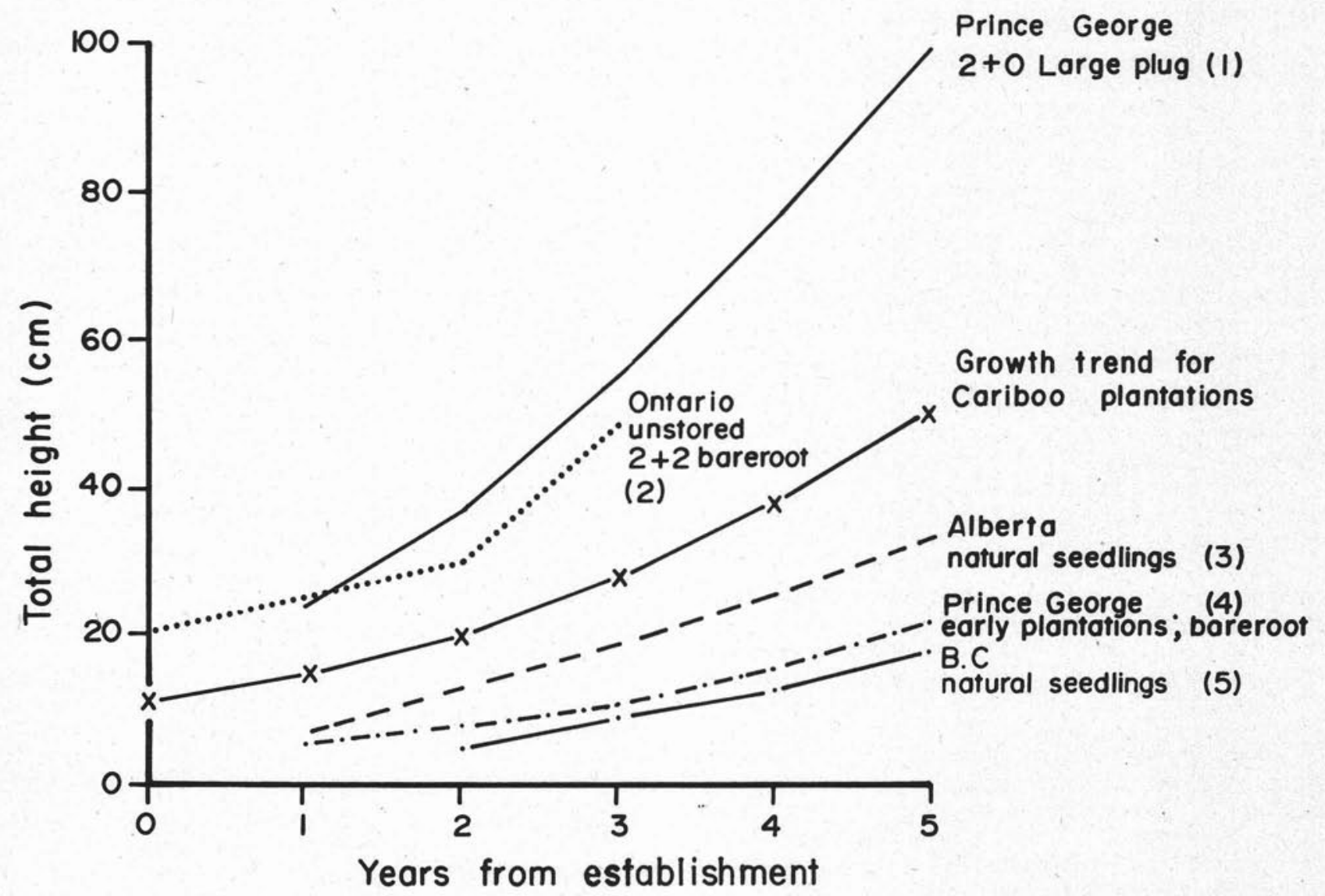

Fig. 5. A comparison of total height-growth curves for plantations and natural regeneration from other surveys.

NOTES

1. Results from experimental plantation established by Van Eerden (1979).

2. Burgar and Lyon (1968).

3. Johnstone (1976) - height/age curve for dominant Picea glauca requiring $5 \mathrm{yrs}$. to reach $0.3 \mathrm{~m}$.

4. Trend prepared by Coates (1974) and based on results of experimental plantations established in early '60's.

5. Trend estimated from results of Eis (1970) for part of Prince George Region, and Smith and Wass (1979) for part of Cariboo Region. 
through competition in dense plantations and concluded that high mortality reduces tree-to-tree variation, and upgrades the vigour of the stand. Dense planting has its costs, as Mitchell notes, but it is evident that in British Columbia, at least, the risks of establishing widely spaced plantations with unimproved seed have not been recognized.

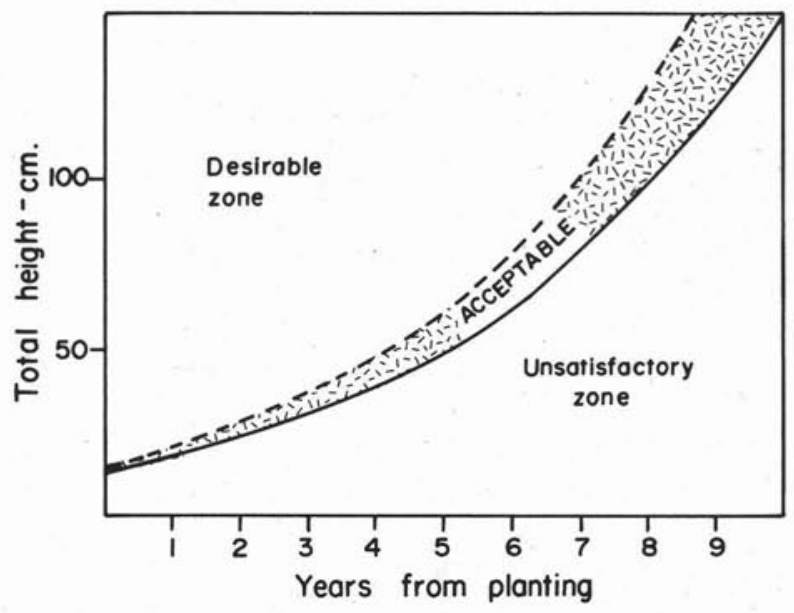

Fig. 6. Interior Spruce Plantation Performance Guide for Cariboo Region, BC

\section{A Plantation Growth Performance Guide}

Figure 6 is a simple guide to plantation growth performance of Interior Spruce in the Cariboo Region. It is most suitable for plantations established in relatively cold soils above $1,000 \mathrm{~m}$ but if used with thought it could be applied throughout the BC Interior. The assessor should measure the total height of 25.40 trees by measuring all those found within a sufficient number of $50 \mathrm{~m}^{2}(0.005 \mathrm{ha})$ plots, in plantations four growing seasons old or more. If the aim is to establish between 750 and 1,000 crop trees per hectare at age 40 , the best four trees in each plot (equivalent to 800 stems/ha) should be selected to calculate a crop tree average for the plantation.

The results of a growth assessment will permit a manager to group plantations into desirable, acceptable and unsatisfactory categories. A desirable plantation is defined as one with a crop tree average better than approximately $85 \%$ of the plantations examined in the study. Attempts should be made to duplicate the conditions which produced the superior results. An acceptable plantation is one which has a crop tree average better than $50 \%$ of those examined. Plantations falling in the unsatisfactory zone must be examined carefully before any remedial treatment is proposed or they are judged unacceptable for administrative purposes. In some plantations total height may not provide a good measure of current performance. For example, a plantation which has been growing slowly may recover and surge in growth, yet still fall below the acceptable line. Assessors must therefore always measure annual height increment for at least the past three growing seasons, and preferably to the time of planting, to establish the possibility of improvement in the performance without remedial action.

Procedures for plantation performance assessment in British Columbia have been prepared by the Ministry of Forests (1980).

\section{Acknowledgements}

The author acknowledges the assistance of Donna Lelacheur who collected many of the data and assisted in data analysis, and the carefully considered review prepared by R. F. Sutton.

\section{References}

Annas, R. and R. Coupé. 1979. Biogeoclimatic zones and subzones of the Cariboo Region. BC Ministry of Forests, Research Branch publication. $103 \mathrm{p}$.

Armit, D. 1970. Comparison of mattock and bar planting methods with white spruce in north central BC. BC Forest Service Research Note 53. 12 p.

Bella, E.I. and J. P. DeFranceschi. 1978. Assessment of regeneration stocking standards used in Alberta: A follow-up. Can. For. Serv., Nor. For. Res. Centre, NOR-X-211. 24 p.

Brix, H. 1979. Effects of plant water stress on photosynthesis and survival of four conifers. Can. J. For. Res. 9: 160-165.

Burdett, N. 1979. Root growth capacity of Interior nursery stock (E. P. 746). BC Min. of Forests, For. Research Review 1978-79. p. 18.

Burdett, N. 1981. Personal communication.

Burgar, R. J. and N. F. Lyon. 1968. Survival and growth of stored and unstored White Spruce planted through the frost-free period. Ont. Dept. Lands and Forests Research Report No. 84. $37 \mathrm{p}$.

Coates, H. 1974. Personal communication.

Coupé, R. 1980. Revised map of biogeoclimatic zones and subzones of the Cariboo Region. BC. Ministry of Forests, Cariboo Region Research Section.

Dobbs, R.C. 1972. Regeneration of White and Engelmann Spruce. Can. For. Serv., Pac. For. Res. Centre, BC-X-69. 77 p.

Eis, 1970. Root growth relationships of juvenile white spruce, alpine fir and lodgepole pine on three soils in the Interior of $\mathrm{BC}$ Can. For. Ser. Pub. No. 1276. 10 p.

Johnstone, W.D. 1976. Juvenile height growth of white spruce and lodgepole pine following logging and scarification in west central Alberta. Can. For. Ser. Nor. For. Res. Centre, NOR$\mathrm{X}-171.10 \mathrm{p}$.

McMinn, R.G. 1976. Is there a better method of mechanical site preparation for spruce-balsam sites? Reforestation Notes Vol. 3 No. 1. p. 6-7.

Ministry of Forests. 1980. Silviculture Manual. Province of British Columbia, Ministry of Forests, Silviculture Branch, Victoria, B.C.

Mitchell, K. J. 1978. Impact of planting density and juvenile spacing on the yield of Douglas-fir in: J. Fries, et al, ed. Growth models for long term forecasting of timber yields. Virginia Poly. I. and S. O. School of For. and Wild Res. FWS-1-78, p. 143-158.

Mullin, R. E. 1964. Reduction in growth of white spruce after outplanting. For. Chron. 40: 488-494.

Pollard, D. E. W. and K. T. Logan. 1977. The effects of light intensity, photo period, soil moisture potential, and temperature on bud morphogenesis in Picea species. Can. J. For. Res. 7: 415-420.

Pollard, D. E. W. and K. T. Logan. 1979. The response of bud morphogenesis in black spruce and white spruce provenances to environmental variables. Can. J. For. Res. 9: 211-217.

Revel, J. 1978. Planting stock standards for the Sub-boreal and boreal biogeoclimatic zones. BC Ministry of Forests, Prince George Forest Region, Silviculture section, unpublished report. $5 \mathrm{p}$.

Smith, R. B. and E. Wass. 1979. Studies on Vunder Fire, Cariboo Forest Region - A Progress Report. Can. For. Serv. Pac. For. Res. Centre unpublished report. $19 p$.

Söderström, V. et al,. 1978. Comparison between planting in mineral soil heaps and after some other soil treatment method. Royal College of Forestry, Umea, Sweden. Dept. of Silv. Res. Note $11.177 \mathrm{p}$.

Stiell, W. M. 1976. White spruce: Artificial regeneration in Canada. Dept. Envir. Can. For. Serv. For. Man. Inst. FMR-X-85. 275 p.

Sutton, R. F. 1972. Constraints on the growth of young white spruce in: R. G. McMinn, ed. White spruce: ecology of a northern resource. Can. For. Serv. Nor. Res. Centre, NOR-X-40, pp. 24-44.

Sutton, R. F. 1980. Techniques for evaluating planting stock quality. IUFRO Workshop N.Z., Aug. 1979. For. Chron. 56: 116-120.

Van Eerden, E. 1975. Growing season production of western conifers in: R. W. Tinus et al., ed. Proceedings of the North American containerized forest tree seedling symposium, Aug. 1974. Denver, Colorado. Great Plains Agric. Council Pub. No. 68, pp. 93-103.

Van Eerden, E. 1979. Personal communication. 